\title{
Bacillus alkalitelluris sp. nov., an alkaliphilic bacterium isolated from sandy soil
}

\author{
Jae-Chan Lee, ${ }^{1}$ Gye Suk Lee, ${ }^{2}$ Dong-Jin Park ${ }^{1}$ and Chang-Jin Kim ${ }^{1}$ \\ ${ }^{1}$ Functional Metabolomics Research Center, Korean Research Institute of Bioscience and \\ Biotechnology (KRIBB), Daejeon 305-806, Republic of Korea \\ ${ }^{2}$ Chungcheongbuk-do Institute of Health and Environment Research, Cheongju 361-290, Republic \\ of Korea
}

Correspondence

Chang-Jin Kim

changjin@kribb.re.kr

\begin{abstract}
A Gram-positive, alkaliphilic bacterium, designated strain $\mathrm{BA}^{2} 88^{\top}$, was isolated from sandy soil. Cells were facultatively anaerobic, endospore-forming rods that were motile by means of peritrichous flagella. The strain grew at $15-40{ }^{\circ} \mathrm{C}$ and $\mathrm{pH} 7.0-11.0$ (optimally at $30{ }^{\circ} \mathrm{C}$ and $\mathrm{pH}$ 9.0-9.5) and at salinities of 0-4\% (w/v) NaCl. Phylogenetic analyses based on 16S rRNA gene sequences showed that strain $B A 288^{\top}$ belonged to the genus Bacillus and that Bacillus herbersteinensis D-1,5a ${ }^{\top}$, Bacillus humi LMG $22167^{\top}$, Bacillus cohnii DSM $6307^{\top}$ and Bacillus litoralis SW-211 ${ }^{\top}$ were the closest neighbours (96.2, 96.0, 96.0 and $95.9 \%$ sequence similarity, respectively). The genomic DNA G $+\mathrm{C}$ content was $37.9 \mathrm{~mol} \%$ and the predominant menaquinone was MK-7. The major cellular fatty acids were anteiso- $C_{15: 0}$, iso- $C_{15: 0,}, \mathrm{C}_{16: 0}$ and iso- $\mathrm{C}_{14: 0}$. The peptidoglycan type was $\mathrm{A} 1 \gamma$ (meso-diaminopimelic acid). Therefore, on the basis of phylogenetic, phenotypic and chemotaxonomic properties, strain BA288 ${ }^{\top}$ represents a novel species of the genus Bacillus, for which the name Bacillus alkalitelluris sp. nov. is proposed. The type strain is $\mathrm{BA}^{288^{\top}}\left(=\mathrm{KCTC} 3947^{\top}=\mathrm{DSM} 16976^{\top}\right)$.
\end{abstract}

Many alkaliphilic and alkalitolerant Bacillus species have been isolated from a wide range of alkaline habitats, such as soda lakes, deserts and arid soils (Li et al., 2002; Ulukanli \& Diurak, 2002; Täubel et al., 2003; Vargas et al., 2005; Yumoto et al., 2003, 2005). At least 19 alkaliphilic and alkalitolerant Bacillus species have been identified to date (Vedder, 1934; Spanka \& Fritze, 1993; Nielsen et al., 1995; Agnew et al., 1995; Fritze, 1996; Switzer Blum et al., 1998; Yumoto et al., 1998, 2003; Olivera et al., 2005; Ghosh et al., 2007). These bacteria constitute the sixth rRNA group in the genus Bacillus (Nielsen et al., 1994) and they have attracted much attention with regard to industrial applications, basic research and biotechnological exploration (Duckworth et al., 1996; Krulwich \& Guffanti, 1989; Martins et al., 2001; Nielsen et al., 1995; Nogi et al., 2005). During screening for alkaliphilic bacteria, we isolated an alkaliphilic bacterium, designated strain BA28 $88^{\mathrm{T}}$, belonging to the genus Bacillus. In this study, we describe the results of a polyphasic study designed to characterize this organism, which was isolated from sandy soil from the Keumsan region of Korea.

The GenBank/EMBL/DDBJ accession number for the $16 \mathrm{~S}$ rRNA gene sequence of strain BA288 ${ }^{\top}$ is AY829448.

Maximum-likelihood and maximum-parsimony phylogenetic trees based on $16 \mathrm{~S}$ rRNA gene sequences for strain $\mathrm{BA} 288^{\top}$ and related taxa are available as supplementary material with the online version of this paper.
During screening for alkaliphilic bacteria, strain $\mathrm{BA} 288^{\mathrm{T}}$ was isolated from sandy soil near an abandoned mine at Keumsan in Korea. For isolation, soil samples were diluted serially with a $1 \%(\mathrm{w} / \mathrm{v})$ saline solution, spread on R2A agar (Difco) adjusted to $\mathrm{pH} 9.2$ by the addition of $\mathrm{Na}_{2} \mathrm{CO}_{3} / \mathrm{NaHCO}_{3}$ and incubated for 2 days at $30{ }^{\circ} \mathrm{C}$. The isolate was routinely cultured aerobically on R2A for 2 days at $30{ }^{\circ} \mathrm{C}$. Growth was tested at different temperatures (4$55{ }^{\circ} \mathrm{C}$ ) and at different $\mathrm{pH}$ values (5.0-11.0) in R2A. Media of different $\mathrm{pH}$ were prepared using the appropriate biological buffers: $\mathrm{Na}_{2} \mathrm{HPO}_{4} / \mathrm{NaH}_{2} \mathrm{PO}_{4}$ for below $\mathrm{pH}$ 8.0, $\mathrm{Na}_{2} \mathrm{CO}_{3} / \mathrm{NaHCO}_{3}$ for $\mathrm{pH} 8.0-10.0$ and $\mathrm{Na}_{2} \mathrm{HPO}_{4} / \mathrm{NaOH}$ for pH 11.0 (Bates \& Bower, 1956; Gomori, 1955). Requirements for, and tolerance of, $\mathrm{NaCl}$ were determined in R2A broth supplemented with $\mathrm{NaCl}$. Cell growth was monitored by measuring the optical density at $600 \mathrm{~nm}$. Cell biomass of strain BA $288^{\mathrm{T}}$ was obtained from cultures grown on R2A at $30{ }^{\circ} \mathrm{C}$. Cell morphology was studied using light microscopy and transmission electron microscopy. Motility was observed after 12 and $36 \mathrm{~h}$ in wet mounts by using a light microscope (E600; Nikon). The flagellum type was examined with transmission electron microscopy, using cells from the exponential growth phase. Cells were mounted on Formvar-coated copper grids and negatively stained with $1 \%$ potassium phosphotungstate $(\mathrm{pH} 7.0)$ and the grids were examined in a Phillips 201 transmission electron microscope operated at $80 \mathrm{kV}$. Endospores were stained according to the method of 
Schaeffer-Fulton (Smibert \& Krieg, 1981). Gram staining was determined using the bioMérieux Gram stain kit according to the manufacturer's instructions. Catalase activity was determined by testing for bubble production in a $3 \%(\mathrm{v} / \mathrm{v})$ aqueous hydrogen peroxide solution. Oxidase activity was determined by testing for oxidation of $1 \%(\mathrm{w} / \mathrm{v})$ tetramethyl-p-phenylenediamine by using a Bactident oxidase strip (Merck). Nitrate reduction and hydrolysis of compounds were determined on R2A according to the methods described by Cowan \& Steel (1965), Lányí (1987) and Smibert \& Krieg (1994). Carbonsource utilization tests and acid-production tests were performed using API $50 \mathrm{CH}$ and API $50 \mathrm{CHB}$ galleries according to the instructions of the manufacturer (bioMérieux). Two drops of cell suspension ( $\mathrm{pH} 9.0$ ) were inoculated into the ampoule. Growth under anaerobic conditions was determined in an anaerobic chamber $\left(\mathrm{H}_{2} /\right.$ $\mathrm{CO}_{2} / \mathrm{N}_{2}, 5: 10: 85$ by vol.; Mart Microbiology) after 5 days incubation at $30{ }^{\circ} \mathrm{C}$ on $\mathrm{R} 2 \mathrm{~A}$.

On R2A medium, strain BA $288^{\mathrm{T}}$ formed cream-coloured, smooth, circular colonies after incubation at $30{ }^{\circ} \mathrm{C}$ for 2 days. The strain grew at salt concentrations in the range $0-4 \%(\mathrm{w} / \mathrm{v}) \mathrm{NaCl}$, with optimum growth occurring at 0 $1 \%(\mathrm{w} / \mathrm{v}) \mathrm{NaCl}$. The strain did not grow in the presence of $\geqslant 5 \%(\mathrm{w} / \mathrm{v}) \mathrm{NaCl}$. Growth was observed at initial $\mathrm{pH}$ of between $\mathrm{pH} 7.0$ and 11.0 in R2A; optimal growth occurred at $\mathrm{pH}$ 9.0-9.5, and no growth was observed at $\mathrm{pH} 6.4$. Growth was observed at temperatures between 15 and $40{ }^{\circ} \mathrm{C}$, the optimum temperature being $30{ }^{\circ} \mathrm{C}$. Strain BA28 $8^{\mathrm{T}}$ comprised Gram-positive, facultatively anaerobic rods, $0.4-0.5 \mu \mathrm{m}$ wide and $2.4-3.0 \mu \mathrm{m}$ long. Terminal, ellipsoidal endospores were formed and cells were motile by means of peritrichous flagella. The strain was oxidaseand catalase-positive and did not reduce nitrate to nitrite. In contrast to its closest neighbours, strain $\mathrm{BA} 288^{\mathrm{T}}$ showed anaerobic growth. The phenotypic characteristics that serve to distinguish strain BA $288^{\mathrm{T}}$ from the type strains of closely related Bacillus species are shown in Table 1.

For quantitative analysis of whole-cell fatty acids, strain $\mathrm{BA} 288^{\mathrm{T}}$ was cultivated on $\mathrm{R} 2 \mathrm{~A}$ adjusted to $\mathrm{pH} 9.0$ for 2 days at $30{ }^{\circ} \mathrm{C}$. Fatty acid methyl esters were analysed by GC/MS according to the instructions of the Microbial Identification System (MIDI; Microbial ID). Isoprenoid quinones were analysed as described by Komagata \& Suzuki (1987), using an HPLC apparatus fitted with a reversed-phase column (GROM-SIL 100 ODS-2FE; GROM). Methanol/2-propanol $(2: 1, \mathrm{v} / \mathrm{v})$ was used as the mobile phase and quinone was detected at $270 \mathrm{~nm}$. The peptidoglycan structure was elucidated by the Identification Service of the Deutsche Sammlung von Mikroorganismen und Zellkulturen (Braunschweig, Germany). Qualitative analyses of amino acids and peptides in peptidoglycan hydrolysates were carried out as described by Schleifer (1985) and Schleifer \& Kandler (1972), using paper chromatography (Rhuland et al., 1955). Quantitative analysis of amino acids in the total hydrolysate was performed using GC and GC/MS as described by MacKenzie (1987) and Hasegawa et al. (1983). The N-terminal residue of the interpeptide bridge was determined by means of dinitrophenylation as described by Schleifer (1985). The $\mathrm{G}+\mathrm{C}$ content (mol\%) was determined by reversed-phase HPLC using the method of Tamaoka \& Komagata (1984).

The predominant isoprenoid quinone of this strain was MK-7. The cell-wall peptidoglycan was of the A1 $\gamma$ type, containing meso-diaminopimelic acid as the diagnostic diamino acid (as is the case in the great majority of the members of the genus Bacillus; Claus \& Berkeley, 1986). The cellular fatty acids comprised anteiso- $\mathrm{C}_{15: 0}(30.9 \%)$, iso- $\mathrm{C}_{15: 0}(16.7 \%), \mathrm{C}_{16: 0}(12.3 \%)$, iso- $\mathrm{C}_{14: 0}(8.2 \%)$, iso$\mathrm{C}_{16: 0}(7.3 \%)$, iso- $\mathrm{C}_{17: 0}(5.8 \%)$, anteiso- $\mathrm{C}_{17: 0}(4.7 \%)$, $\mathrm{C}_{16: 1} \omega 11 c(3.9 \%), \mathrm{C}_{15: 0}(1.4 \%), \mathrm{C}_{17: 0}(1.3 \%), \mathrm{C}_{16: 1} \omega 7 c$ alcohol $(0.9 \%), \mathrm{C}_{18: 0}(0.5 \%), \mathrm{C}_{16: 0} \mathrm{~N}$ alcohol $(0.5 \%)$, $\mathrm{C}_{17: 1} \omega 5 c(0.5 \%)$ and $\mathrm{C}_{17: 1} \omega 10 c(0.4 \%)$. The presence of branched, saturated fatty acids as the major fatty acids corresponded with the profiles for the type strains of the genus Bacillus (Kämpfer, 1994). Fatty acids anteiso- $C_{15: 0}$ and iso- $\mathrm{C}_{15: 0}$ were major components in strain $\mathrm{BA} 288^{\mathrm{T}}$; the most closely related type strains, Bacillus herbersteinensis D-1,5 $\mathrm{a}^{\mathrm{T}}$, Bacillus humi LMG $22167^{\mathrm{T}}$ and Bacillus litoralis $\mathrm{SW}-211^{\mathrm{T}}$, showed similar components. Comparative 16S rRNA gene sequence analysis showed that the isolate was most closely related to $B$. herbersteinensis $\mathrm{D}-1,5 \mathrm{a}^{\mathrm{T}}$, B. humi LMG $22167^{\mathrm{T}}$, B. cohnii DSM $6307^{\mathrm{T}}$ and $B$. litoralis $\mathrm{SW}-211^{\mathrm{T}}$, with sequence similarities of 96.2 , 96.0, 96.0 and $95.9 \%$, respectively. These similarities are sufficiently low $(<97 \%)$ to justify the definition of a novel species (Rosselló-Mora \& Amann, 2001; Stackebrandt et al., 2002). The DNA G + C content of strain BA288 ${ }^{\mathrm{T}}$ was $37.9 \mathrm{~mol} \%$. The major fatty acid profile, the major isoprenoid quinone and the DNA G $+\mathrm{C}$ content are typical of the group classically defined as the genus Bacillus (Arahal et al., 1999; Fritze, 1996; Nielsen et al., 1994, 1995; Priest et al., 1988).

The 16S rRNA gene was amplified using a PCR with the Eubac 27F and 1492R primers (DeLong, 1992) and the PCR products were purified using the QIAquick PCR purification kit (Qiagen). Sequencing of the purified 16S rRNA gene was performed using an ABI PRISM BigDye Terminator cycle sequencing kit (Applied Biosystems), as recommended by the manufacturer, and five primers $(337 \mathrm{~F}, 785 \mathrm{~F}, 1225 \mathrm{~F}$, $518 \mathrm{R}, 1100 \mathrm{R})$. The purified sequencing reaction mixtures were electrophoresed automatically using an Applied Biosystems model 377 automatic DNA sequencer. The $16 \mathrm{~S}$ rRNA gene sequence of strain $\mathrm{BA} 288^{\mathrm{T}}$ was aligned with those of Bacillus species by using the CLUSTAL $\mathrm{W}$ program (Thompson et al., 1994). Sequence similarity values were computed using Similarity Matrix, version 1.1 (Ribosomal Database Project II; http://rdp.cme.msu.edu/; Cole et al., 2007). Gaps at the $5^{\prime}$ and $3^{\prime}$ ends of the alignment were included for further analysis. Phylogenetic trees were inferred using three tree-making algorithms, i.e. neighbour joining (Saitou \& Nei, 1987), maximum likelihood (Felsenstein, 1981) and maximum parsimony (Kluge \& Farris, 1969), 
Table 1. Characteristics that serve to differentiate strain $B A 288^{\top}$ from related Bacillus species

Taxa: 1, strain BA288 ${ }^{\mathrm{T}}$; 2, B. litoralis (data from Yoon \& Oh, 2005); 3, B. herbersteinensis (Wieser et al., 2005); 4, B. humi (Heyrman et al., 2005); 5, B. endophyticus (Reva et al., 2002); 6, B. asahii (Yumoto et al., 2004); 7, B. funiculus (Ajithkumar et al., 2002); 8, B. cibi (Yoon et al., 2005); 9, B. indicus (Suresh et al., 2004); 10, B. horikoshii (Nielsen et al., 1995; Li et al., 2002; Logan et al., 2002); 11, B. halmapalus (Nielsen et al., 1995; Li et al., 2002; Logan et al., 2002); 12, B. cohnii (Spanka \& Fritze, 1993; Suresh et al., 2004); 13, B. flexus (Claus \& Berkeley, 1986; Suresh et al., 2004); 14, B. megaterium (Claus \& Berkeley, 1986; Reva et al., 2002; Täubel et al., 2003); 15, B. simplex (Priest et al., 1988; De Clerck et al., 2004). In all cases, cells are catalase-positive rods. +, Positive; - , negative; w, weakly positive; v, variable; ND, no data available. Data in parentheses are for the respective type strains.

\begin{tabular}{|c|c|c|c|c|c|c|c|c|c|c|c|c|c|c|c|}
\hline Characteristic & 1 & 2 & 3 & 4 & 5 & 6 & 7 & 8 & 9 & 10 & 11 & 12 & 13 & 14 & 15 \\
\hline Spore position $\dagger$ & $\mathrm{T}$ & $\mathrm{C}, \mathrm{S}$ or $\mathrm{T}$ & $\mathrm{T}$ & $\mathrm{S}$ or $\mathrm{T}$ & or $\mathrm{T}$ & C & $\mathrm{C}$ & $\mathrm{C}$ or $\mathrm{s}$ & s & s & $\mathrm{C}$ or $\mathrm{s}$ & $\mathrm{T}$ & ND & C & $\begin{array}{l}C, S \text { or } \\
T\end{array}$ \\
\hline Oxidase & + & + & + & + & + & + & - & + & ND & ND & ND & + & ND & - & - \\
\hline Anaerobic growth & + & - & - & $\mathrm{w}$ & - & - & - & - & - & - & - & ND & $\mathrm{ND}$ & - & - \\
\hline $10 \%(\mathrm{w} / \mathrm{v}) \mathrm{NaCl}$ & - & + & - & ND & + & - & - & + & - & - & - & - & ND & - & - \\
\hline $10^{\circ} \mathrm{C}$ & - & + & + & - & + & - & - & + & - & + & + & + & ND & + & $\mathrm{ND}$ \\
\hline $45^{\circ} \mathrm{C}$ & - & + & - & - & + & + & - & + & - & - & - & + & ND & $\mathrm{ND}$ & ND \\
\hline Nitrate reduction & - & - & - & + & - & $\mathrm{w}$ & + & - & - & - & - & + & - & - & + \\
\hline \multicolumn{16}{|l|}{ Hydrolysis of: } \\
\hline Aesculin & + & + & ND & + & $\mathrm{ND}$ & $\mathrm{ND}$ & + & + & + & + & + & $(-)$ & - & + & - \\
\hline Tween 80 & - & + & ND & $\mathrm{ND}$ & ND & $\mathrm{ND}$ & - & + & ND & - & - & $\mathrm{V}(+)$ & $\mathrm{ND}$ & $\mathrm{ND}$ & $\mathrm{V}$ \\
\hline \multicolumn{16}{|l|}{ Growth on: } \\
\hline D-Galactose & - & + & + & - & $\mathrm{ND}$ & $\mathrm{ND}$ & ND & + & ND & - & - & ND & $\mathrm{ND}$ & $(-)$ & $\mathrm{ND}$ \\
\hline Cellobiose & - & + & + & - & ND & $\mathrm{ND}$ & ND & + & + & ND & ND & $(-)$ & + & $(-)$ & $\mathrm{V}$ \\
\hline D-Mannose & - & - & + & - & ND & $\mathrm{ND}$ & ND & + & + & $\mathrm{V}$ & + & $(-)$ & - & $(-)$ & - \\
\hline Sucrose & - & + & + & - & ND & $\mathrm{ND}$ & + & + & + & ND & ND & $(-)$ & + & $(-)$ & $\mathrm{ND}$ \\
\hline Maltose & - & + & + & - & ND & $\mathrm{ND}$ & + & + & + & ND & ND & $(-)$ & + & $(+)$ & - \\
\hline Pyruvate & - & + & + & - & ND & $\mathrm{ND}$ & ND & + & - & ND & ND & $(+)$ & - & $(-)$ & $\mathrm{ND}$ \\
\hline \multicolumn{16}{|l|}{ Acid production from: } \\
\hline D-Glucose & - & + & - & - & + & - & + & + & - & + & + & $(-)$ & + & + & + \\
\hline Lactose & - & + & - & + & - & - & $\mathrm{ND}$ & - & - & - & - & $(-)$ & - & V & - \\
\hline
\end{tabular}

${ }^{\star} \mathrm{C}$, Cylindrical; E, ellipsoidal or oval; s, spherical.

$\dagger_{\mathrm{C}}$, Central or paracentral; s, subterminal; $\mathrm{T}$, terminal.

available in the PHYLIP software package (version 3.6) (Felsenstein, 2002). Evolutionary distance matrices for the neighbour-joining method were calculated using the algorithm of Kimura's two-parameter model (Kimura, 1980) with the DNADIST program. To evaluate the stability of the phylogenetic tree, a bootstrap analysis (with 1000 replications) was performed with the SEQBOOT, DNADIST, NEIGHBOR and CONSENSE programs in the PHYLIP package.

The almost-complete 16S rRNA gene sequence (1515 nt) of strain BA288 ${ }^{\mathrm{T}}$ was obtained and used for an initial BLAST search in GenBank and for phylogenetic analysis. A phylogenetic analysis based on 16S rRNA gene sequences showed that strain $\mathrm{BA} 288^{\mathrm{T}}$ formed a distinct line within the genus Bacillus and joined a clade with the type strain of $B$. litoralis in the neighbour-joining analysis (Fig. 1). Phylogenetic trees constructed using the maximum-likelihood and maximum-parsimony algorithms also supported the positioning of strain $\mathrm{BA} 288^{\mathrm{T}}$ in a clade with the type strain of B. litoralis (see Supplementary Figs S1 and S2, available in IJSEM 


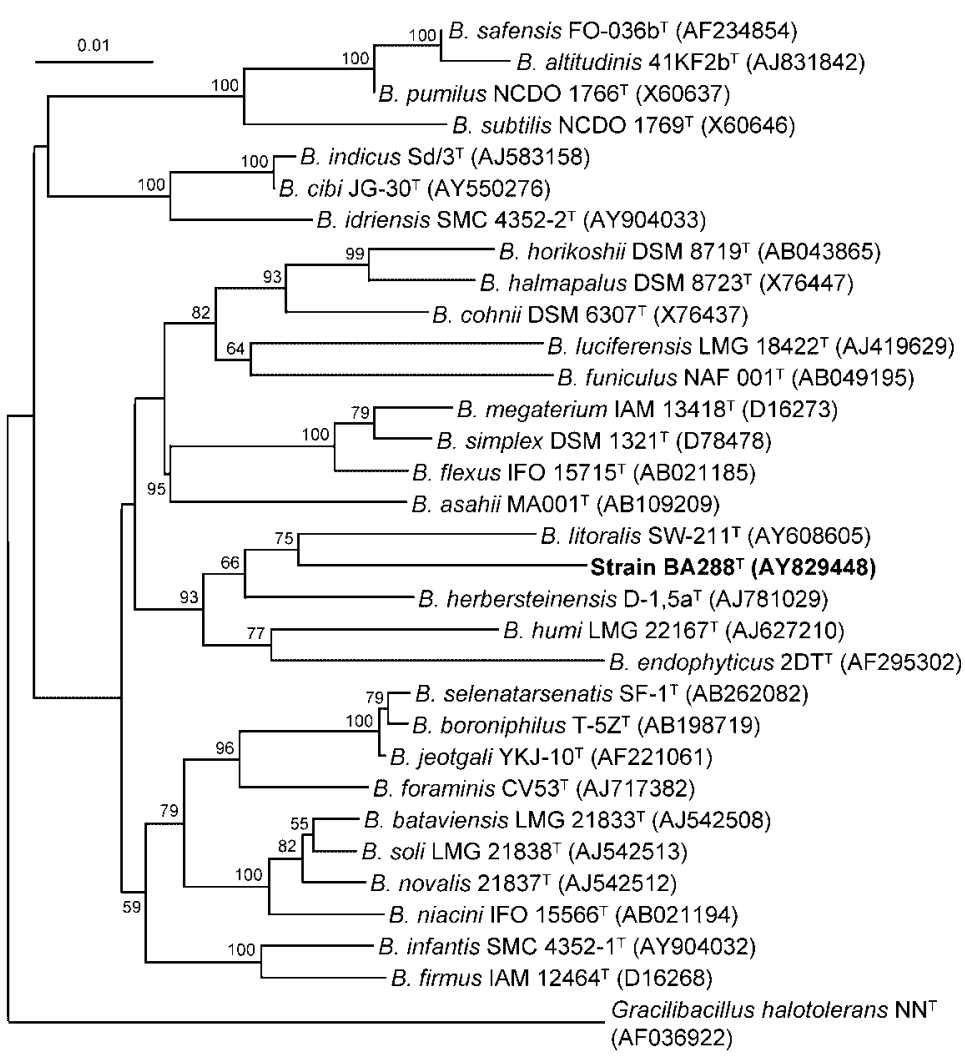

Fig. 1. Neighbour-joining phylogenetic tree, based on 16S rRNA gene sequences, showing the relationships between strain BA288 ${ }^{\top}$ and related taxa. Numbers at branching nodes are bootstrap percentages (based on 1000 replications); only values greater than $50 \%$ are indicated. Bar, 0.01 substitutions per nucleotide position.
Online). Comparative 16S rRNA gene sequence analysis showed that the isolate was most closely related to $B$. herbersteinensis $\mathrm{D}-1,5 \mathrm{a}^{\mathrm{T}}$, B. humi LMG $22167^{\mathrm{T}}$, B. cohnii DSM $6307^{\mathrm{T}}$ and $B$. litoralis $\mathrm{SW}-211^{\mathrm{T}}$, with sequence similarities of $96.2,96.0,96.0$ and $95.9 \%$, respectively: these levels of similarity are sufficiently low $(<97 \%)$ to justify defining the isolate as a representative of a novel species (Rosselló-Mora \& Amann, 2001; Stackebrandt et al., 2002).

Therefore, on the basis of physiological, biochemical and phylogenetic properties, strain $\mathrm{BA} 288^{\mathrm{T}}$ represents a novel species within the genus Bacillus, for which the name Bacillus alkalitelluris sp. nov. is proposed.

\section{Description of Bacillus alkalitelluris sp. nov.}

Bacillus alkalitelluris (al.ka.li.tel.lu'ris. N.L. n. alkali alkali; L. gen. n. telluris of the soil or earth; N.L. gen. n. alkalitelluris of alkaline soil).

Cells are facultatively anaerobic, Gram-positive, endospore-forming (ellipsoidal, terminal) rods, 0.4-0.5 ×2.4$3.0 \mu \mathrm{m}$. Colonies on R2A are creamy, smooth and circular. Cells are motile rods with peritrichous flagella. Grows at salinities of $0-4 \%(\mathrm{w} / \mathrm{v}) \mathrm{NaCl}$. Optimal growth occurs at $0-1 \%(\mathrm{w} / \mathrm{v}) \mathrm{NaCl}$. No growth occurs in the presence of $\geqslant 5 \%(\mathrm{w} / \mathrm{v}) \mathrm{NaCl}$. Grows between 15 and $40{ }^{\circ} \mathrm{C}$ (optimally at $30{ }^{\circ} \mathrm{C}$ ) and from $\mathrm{pH} 7.0$ to 11.0 (optimally at $\mathrm{pH} 9.0-$ 9.5) in R2A broth. Growth occurs under anaerobic conditions on R2A agar. Oxidase- and catalase-positive. Nitrate is not reduced to nitrite. $\mathrm{H} 2 \mathrm{~S}$ and indole are not produced. Aesculin and starch are hydrolysed. Casein, gelatin, Tweens 80 and 20, xanthine and hypoxanthine are not hydrolysed. Acids are produced from potassium 5-ketogluconate and aesculin, but not from L-arabinose, D-arabitol, D-fructose, D-galactose, gentiobiose, glycogen, D-glucose, inositol, D-lactose, D-mannitol, D-mannose, melezitose, raffinose, L-rhamnose, D-sorbitol, salicin, D-tagatose, turanose, xylitol or D-xylose. The following substrates are not utilized for growth: L-arabinose, cellobiose, D-fructose, D-galactose, D-glucose, lactose, D-mannose, maltose, sucrose and pyruvate. Acetate, benzoate, citrate, formate, L-glutamate, L-malate, succinate and D-xylose are utilized. The cell-wall peptidoglycan contains meso-diaminopimelic acid (A $1 \gamma$ type). The predominant isoprenoid quinone is $\mathrm{MK}-7$. The major fatty acids are anteiso- $\mathrm{C}_{15: 0}$, iso- $\mathrm{C}_{15: 0}$ and $\mathrm{C}_{16: 0}$. The DNA $\mathrm{G}+\mathrm{C}$ content of the type strain is $37.9 \mathrm{~mol} \%$.

The type strain, BA288 ${ }^{\mathrm{T}}\left(=\mathrm{KCTC} 3947^{\mathrm{T}}=\mathrm{DSM} 16976^{\mathrm{T}}\right)$, was isolated from sandy soil near an abandoned mine in the Keumsan region of Korea.

\section{Acknowledgements}

This work was supported by the 21C Frontier Microbial Genomics and Application Centre Program of the Korean Ministry of Science and Technology and by the KRIBB Research Initiative Program, Republic of Korea. 


\section{References}

Agnew, M. D., Koval, S. F. \& Jarrell, K. F. (1995). Isolation and characterization of novel alkaliphiles from bauxite-processing waste and description of Bacillus vedderi sp. nov., a new obligate alkaliphile. Syst Appl Microbiol 18, 221-230.

Ajithkumar, V. P., Ajithkumar, B., Lriye, R. \& Sakai, T. (2002). Bacillus funiculus sp. nov., filamentous isolates from activated sludge. Int J Syst Evol Microbiol 52, 1141-1144

Arahal, D. R., Marquez, M. C., Volcani, B. E., Schleifer, K. H. \& Ventosa, A. (1999). Bacillus marismortui sp. nov., a new moderately halophilic species from the Dead Sea. Int J Syst Bacteriol 49, 521-530.

Bates, R. G. \& Bower, V. E. (1956). Alkaline solutions for $\mathrm{pH}$ control. Anal Chem 28, 1322-1324.

Claus, D. \& Berkeley, R. C. W. (1986). Genus Bacillus Cohn 1872. In Bergey's Manual of Systematic Bacteriology, vol. 2, pp. 1105-1140. Edited by P. H. A. Sneath, N. S. Mair, M. E. Sharpe \& J. G. Holt. Baltimore: Williams \& Wilkins.

Cole, J. R., Chai, B., Farris, R. J., Wang, Q., Kulam-Syed-Mohideen, A. S., McGarrell, D. M., Bandela, A. M., Cardenas, E., Garrity, G. M. \& Tiedje, J. M. (2007). The ribosomal database project (RDP-II): introducing $m y R D P$ space and quality controlled public data. Nucleic Acids Res 35, D169-D172.

Cowan, S. T. \& Steel, K. J. (1965). Manual for the Identification of Medical Bacteria. London: Cambridge University Press.

De Clerck, E., Rodríguez-Díaz, M., Vanhoutte, T., Heyman, J., Logan, N. A. \& De Vos, P. (2004). Anoxybacillus contaminans sp. nov. and Bacillus gelatini sp. nov., isolated from contaminated gelatin batches. Int J Syst Evol Microbiol 54, 941-946.

DeLong, E. F. (1992). Archaea in coastal marine environments. Proc Natl Acad Sci U S A 89, 5685-5689.

Duckworth, A. W., Grant, W. D., Jones, B. E. \& Steenbergen, R. V. (1996). Phylogenetic diversity of soda lake alkaliphiles. FEMS Microbiol Ecol 19, 181-191.

Felsenstein, J. (1981). Evolutionary trees from DNA sequences: a maximum likelihood approach. J Mol Evol 17, 368-376.

Felsenstein, J. (2002). PHYLIP (phylogeny inference package), version 3.6a. Distributed by the author. Department of Genome Sciences, University of Washington, Seattle, USA.

Fritze, D. (1996). Bacillus haloalkaliphilus sp. nov. Int J Syst Bacteriol 46, 98-101.

Ghosh, A., Bhardwaj, M., Satyanarayana, T., Khurana, M., Mayilraj, S. \& Jain, R. K. (2007). Bacillus lehensis sp. nov., an alkalitolerant bacterium isolated from soil. Int J Syst Evol Microbiol 57, 238-242.

Gomori, G. (1955). Preparation of buffers for use in enzyme studies. Methods Enzymol 1, 138-146.

Hasegawa, T., Takizawa, M. \& Tanida, S. (1983). A rapid analysis for chemical grouping of aerobic actinomycetes. J Gen Appl Microbiol 29, 319-322.

Heyrman, J., Rodríguez-Díaz, M., Devos, J., Felske, A., Logan, N. A. \& De Vos, P. (2005). Bacillus arenosi sp. nov., Bacillus arvi sp. nov. and Bacillus humi sp. nov., isolated from soil. Int J Syst Evol Microbiol 55, 111-117.

Kämpfer, P. (1994). Limits and possibilities of total fatty acid analysis for classification and identification of Bacillus species. Syst Appl Microbiol 17, 86-98.

Kimura, M. (1980). A simple method for estimating evolutionary rates of base substitutions through comparative studies of nucleotide sequences. J Mol Evol 16, 111-120.
Kluge, A. G. \& Farris, F. S. (1969). Quantitative phyletics and the evolution of anurans. Syst Zool 18, 1-32.

Komagata, K. \& Suzuki, K. (1987). Lipid and cell-wall analysis in bacterial systematics. Methods Microbiol 19, 161-207.

Krulwich, T. A. \& Guffanti, A. A. (1989). Alkalophilic bacteria. Annu Rev Microbiol 43, 435-463.

Lányí, B. (1987). Classical and rapid identification methods for medically important bacteria. Methods Microbiol 19, 1-67.

Li, Z., Kawamura, Y., Shida, O., Yamagata, S., Deguchi, T. \& Ezaki, T. (2002). Bacillus okuhidensis sp. nov., isolated from the Okuhida spa area of Japan. Int J Syst Evol Microbiol 52, 1205-1209.

Logan, N. A., Lebbe, L., Verhelst, A., Goris, J., Forsyth, G., RodriguezDiaz, M., Heyndrickx, M. \& De Vos, P. (2002). Bacillus luciferensis sp. nov., from volcanic soil on Candlemas Island, South Sandwich archipelago. Int J Syst Evol Microbiol 52, 1985-1989.

MacKenzie, S. L. (1987). Gas chromatographic analysis of amino acids as the N-heptafluorobutyryl isobutyl esters. J Assoc Off Anal Chem 70, 151-160.

Martins, R. F., Davids, W., Abu Al-Soud, W., Levander, F., Rådström, P. \& Hatti-Kaul, R. (2001). Starch-hydrolyzing bacteria from Ethiopian soda lakes. Extremophiles 5, 135-144.

Nielsen, P., Rainey, F. A., Outtrup, H., Priest, F. G. \& Fritze, D. (1994). Comparative $16 \mathrm{~S}$ rDNA sequence analysis of some alkaliphilic bacilli and the establishment of a sixth rRNA group within the genus Bacillus. FEMS Microbiol Lett 117, 16-65.

Nielsen, P., Fritze, D. \& Priest, F. G. (1995). Phenetic diversity of alkaliphilic Bacillus strains: proposal for nine new species. Microbiology 141, 1745-1761.

Nogi, Y., Takami, H. \& Horikoshi, K. (2005). Characterization of alkaliphilic Bacillus strains used in industry: proposal of five novel species. Int J Syst Evol Microbiol 55, 2309-2315.

Olivera, N., Siñeriz, F. \& Breccia, J. D. (2005). Bacillus patagoniensis sp. nov., a novel alkalitolerant bacterium from the rhizosphere of Atriplex lampa in Patagonia, Argentina. Int J Syst Evol Microbiol 55, 443-447.

Priest, F. G., Goodfellow, M. \& Todd, C. (1988). A numerical classification of the genus Bacillus. J Gen Microbiol 134, 1847-1882.

Reva, O. N., Smirnov, V. V., Pettersson, B. \& Priest, F. G. (2002). Bacillus endophyticus sp. nov., isolated from the inner tissues of cotton plants (Gossypium sp.). Int J Syst Evol Microbiol 52, 101-107.

Rhuland, L. E., Work, E., Denman, R. F. \& Hoare, D. S. (1955). The behavior of the isomers of $\alpha, \varepsilon$-diaminopimelic acid on paper chromatograms. J Am Chem Soc 77, 4844-4846.

Rosselló-Mora, R. \& Amann, R. (2001). The species concept for prokaryotes. FEMS Microbiol Rev 25, 39-67.

Saitou, N. \& Nei, M. (1987). The neighbor-joining method: a new method for reconstructing phylogenetic trees. Mol Biol Evol 4, 406425.

Schleifer, K. H. (1985). Analysis of the chemical composition and primary structure of murein. Methods Microbiol 18, 123-156.

Schleifer, K. H. \& Kandler, O. (1972). Peptidoglycan types of bacterial cell walls and their taxonomic implications. Bacteriol Rev 36, 407-477.

Smibert, R. M. \& Krieg, N. R. (1981). General characterization. In Manual of Methods for General Microbiology, pp. 409-443. Edited by P. Gerhardt, R. G. E. Murray, R. N. Costilow, E. W. Nester, W. A. Wood, N. R. Krieg \& G. B. Phillips. Washington, DC: American Society for Microbiology.

Smibert, R. M. \& Krieg, N. R. (1994). Phenotypic characterization. In Methods for General and Molecular Bacteriology, pp. 607-654. Edited by P. Gerhardt. Washington, DC: American Society for Microbiology. 
Spanka, R. \& Fritze, D. (1993). Bacillus cohnii sp. nov., a new, obligately alkaliphilic, oval-spore-forming Bacillus species with ornithine and aspartic acid instead of diaminopimelic acid in the cell wall. Int J Syst Bacteriol 43, 150-156.

Stackebrandt, E., Frederikson, W., Garrity, G. M., Grimont, P. A. D., Kämpfer, P., Maiden, M. C. J., Nesme, X., Rosselló-Mora, R., Swings, J. \& other authors (2002). Report of the ad hoc committee for the reevaluation of the species definition in bacteriology. Int J Syst Evol Microbiol 52, 1043-1047.

Suresh, K., Prabagaran, S. R., Sengupta, S. \& Shivaji, S. (2004). Bacillus indicus sp. nov., an arsenic-resistant bacterium isolated from an aquifer in West Bengal, India. Int J Syst Evol Microbiol 54, 13691375.

Switzer Blum, J., Burns Bindi, A., Buzzelli, J., Stolz, J. F. \& Oremland, R. S. (1998). Bacillus arsenicoselenatis sp. nov., and Bacillus selenitireducens sp. nov.: two haloalkaliphiles from Mono Lake, California that respire oxyanions of selenium and arsenic. Arch Microbiol 171, 19-30.

Tamaoka, J. \& Komagata, K. (1984). Determination of DNA base composition by reversed-phase high-performance liquid chromatography. FEMS Microbiol Lett 25, 125-128.

Täubel, M., Kämpfer, P., Buczolits, S., Lubitz, W. \& Busse, H.-J. (2003). Bacillus barbaricus sp. nov., isolated from an experimental wall painting. Int J Syst Evol Microbiol 53, 725-730.

Thompson, J. D., Higgins, D. G. \& Gibson, T. J. (1994). ClustaL W: improving the sensitivity of progressive multiple sequence alignment through sequence weighting, position-specific gap penalties and weight matrix choice. Nucleic Acids Res 22, 4673-4680.

Ulukanli, Z. \& Diurak, M. (2002). Alkaliphilic microorganisms and habitats. Turk J Biol 26, 181-191.
Vargas, V. A., Delgado, O. D., Hatti-Kaul, R. \& Mattiasson, B. (2005). Bacillus bogoriensis sp. nov., a novel alkaliphilic, halotolerant bacterium isolated from a Kenyan soda lake. Int J Syst Evol Microbiol 55, 899-902.

Vedder, A. (1934). Bacillus alcalophilus n. sp.; benevens enkele ervaringen met sterk alcalische voedingbodems. Antonie van Leeuwenhoek 1, 141-147 (in Dutch).

Wieser, M., Worliczek, H., Kämpfer, P. \& Busse, H.-J. (2005). Bacillus herbersteinensis sp. nov. Int J Syst Evol Microbiol 55, 2119-2123.

Yoon, J.-H. \& Oh, T.-K. (2005). Bacillus litoralis sp. nov., isolated from a tidal flat of the Yellow Sea in Korea. Int J Syst Evol Microbiol 55, 1945-1948.

Yoon, J.-H., Lee, C.-H. \& Oh, T.-K. (2005). Bacillus cibi sp. nov., isolated from jeotgal, a traditional Korean fermented seafood. Int $J$ Syst Evol Microbiol 55, 733-736.

Yumoto, I., Yamazaki, K., Sawabe, T., Nakano, K., Kawasaki, K., Ezura, Y. \& Shinano, H. (1998). Bacillus horti sp. nov., a new Gramnegative alkaliphilic bacillus. Int J Syst Bacteriol 48, 565-571.

Yumoto, I., Yamaga, S., Sogabe, Y., Nodasaka, Y., Matsuyama, H., Nakajima, K. \& Suemori, A. (2003). Bacillus krulwichiae sp. nov., a halotolerant obligate alkaliphile that utilizes benzoate and $\mathrm{m}$ hydroxybenzoate. Int J Syst Evol Microbiol 53, 1531-1536.

Yumoto, I., Hirota, K., Yamaga, S., Nodasaka, Y., Kawasaki, T., Matsuyama, H. \& Nakajima, K. (2004). Bacillus asahii sp. nov., a novel bacterium isolated from soil with the ability to deodorize the bad smell generated from short-chain fatty acids. Int J Syst Evol Microbiol 54, 1997-2001.

Yumoto, I., Hirota, K., Goto, T., Nodasaka, Y. \& Nakajima, K. (2005). Bacillus oshimensis sp. nov., a moderately halophilic, non-motile alkaliphile. Int J Syst Evol Microbiol 55, 907-911. 